\title{
Survival and Persistence of Alternaria dauci in Carrot Cropping Systems
}

\author{
B. M. Pryor, Department of Plant Pathology, University of California, Davis 95616; J. O. Strandberg, Department \\ of Plant Pathology, University of Florida, Mid-Florida Research and Education Center, Apopka 32703; R. M. \\ Davis, Department of Plant Pathology, University of California, Davis; J. J. Nunez, Kern County Cooperative Ex- \\ tension, Bakersfield, CA 93307; and R. L. Gilbertson, Department of Plant Pathology, University of California, \\ Davis
}

\begin{abstract}
Pryor, B. M., Strandberg, J. O., Davis, R. M., Nunez, J. J., and Gilbertson, R. L. 2002. Survival and persistence of Alternaria dauci in carrot cropping systems. Plant Dis. 86:1115-1122.

Alternaria dauci was recovered in California from carrot crop residue and from volunteer carrot plants in fallow carrot fields. The fungus was not recovered from common weeds surrounding fallow fields. To evaluate further the survival of $A$. dauci on carrot crop residue, infected carrot leaf tissue was placed in fields or in soil in greenhouse pots, and recovered over time. In California, A. dauci was recovered from infected leaf tissue in both fallow and irrigated fields for as long as 1 year. In Florida, $A$. dauci was recovered from infected leaf tissue in fallow fields for up to 30 weeks. In greenhouse experiments, $A$. dauci was recovered from infected leaf tissue for as long as 1 year in dry soil, but only up to 30 weeks in soil that was watered weekly. To determine the infectivity of $A$. dauci borne on carrot crop residue, infected carrot crops were incorporated into organic and mineral field soils, and soil samples were collected over time. Carrot seed were planted in collected soil, and seedling infection by A. dauci was recorded. Seedling infection was detected up to 13 and 14 weeks after crop incorporation in organic and mineral soil, respectively. Seedling infection was detected for up to 5 weeks in soil that remained dry compared with 3 weeks in flooded soil.
\end{abstract}

Additional keywords: Daucus carota, disease management, pathogen survival, soilborne inoculum

Alternaria leaf blight (ALB), caused by Alternaria dauci (Kühn) Groves \& Skolko, is probably the most common and destructive disease of carrot (Daucus carota L.) worldwide (8). Symptoms begin on carrot leaflets and petioles as small necrotic lesions, which are often surrounded by a chlorotic halo. Under optimal conditions for ALB, lesions can coalesce and blight the entire leaf. Typically, A. dauci sporulates readily on diseased tissue $(4,16)$. The conidia easily become airborne and can spread to other leaves of the same plant and to other carrot plants and neighboring carrot fields, resulting in epidemics of ALB $(4,8,16)$. Under favorable conditions, ALB may reduce carrot yields significantly due to loss of photosynthetic

Corresponding author: B. M. Pryor

E-mail: bmpryor@ag.arizona.edu

Current address of B. M. Pryor: Department of Plant Pathology, P. O. Box 210036, University of Arizona, Tucson, AZ 85721.

This work was sponsored, in part, by the California Fresh Carrot Advisory Board, and by the College of Agriculture and Environmental Studies at the University of California, Davis.

Accepted for publication 20 May 2002.

Publication no. D-2002-0729-01R

(C) 2002 The American Phytopathological Society tissue, or may cause complete loss of a crop when collapse of the crop canopy prevents mechanical harvest. The fungus also can infect carrot seed crops, resulting in the infestation or infection of commercial carrot seed (17). Planting of infested commercial carrot seed has probably contributed to the spread of $A$. dauci into new carrot production areas and resulted in a worldwide distribution of ALB $(5,14,21)$.

Development of ALB can be suppressed by the use of fungicides, such as iprodione, captafol, azoxystrobin, mancozeb, and chlorothalonil $(11,23)$, but this approach to disease management is costly and not always effective. In addition, development of fungicide resistance, particularly to iprodione, has been documented for many Alternaria spp., including A. dauci $(2,13)$. ALBtolerant carrot cultivars have been developed and provide varying levels of disease control, but no carrot cultivars are immune (12). Other management tactics include reducing levels of seedborne inoculum through the use of fungicide- or hot water-treated seed, and the use of certified pathogen-free seed $(5,14,18,21)$. However, ALB epidemics continue to occur even when treated or pathogen-free seed is planted, suggesting that other sources of primary inoculum may initiate these epidemics.

A. dauci can survive for years as conidia on seed or on filter paper under laboratory conditions (19), which suggests that, under the right field conditions, the pathogen may persist on carrot crop residue or in soil. Previous studies have shown that $A$. dauci-infested carrot crop residue can serve as a source of inoculum for ALB on carrot seedlings (15). However, these studies did not address the survival and infectivity of $A$. dauci on carrot crop residue over time. Research on the survival of other species of Alternaria, such as $A$. macrospora on cotton (9), A. solani on tomato $(3,6)$, and $A$ helianthi on sunflower (1), has demonstrated long-term (overseason) survival of these pathogens in association with crop residue. Similarities in the biology of many Alternaria spp. suggest that over-seasoning in crop residue may occur with other diseases caused by Alternaria spp. as well $(10,22)$.

A. dauci has been recovered from a limited number of weed hosts associated with carrot production in New Zealand, including wild carrot, wild parsnip, and Fumaria muralis (15). However, comprehensive surveys of potential weed hosts of $A$. dauci in other regions of carrot production have not been conducted. Volunteer carrot plants (i.e., carrot roots that remain in the field following harvest and later resprout) represent another potential source of disease inoculum, but there is little documentation of the survival and dispersal of $A$. dauci in association with volunteer carrot plants. Thus, additional knowledge about the survival of $A$. dauci in the absence of carrot crops is needed in order to manage ALB effectively and consistently.

The objective of this study was to examine the survival and persistence of $A$. dauci in carrot fields from two areas of carrot production that differ greatly in regard to environmental conditions. Experiments were conducted in California, which includes areas of carrot production that are hot and dry, and in Florida, which includes areas of carrot production that are warm and wet. These two regions likely represent climate extremes associated with commercial carrot production, and the results of this study should be relevant to improved ALB management in other areas of carrot production throughout the world.

\section{MATERIALS AND METHODS}

Occurrence of $A$. dauci on volunteer carrot plants and weeds in California. Fallow carrot fields in Kern County, CA, 
were surveyed in late winter and early spring (February and March) for volunteer carrot plants and for weeds that might be infected with $A$. dauci. All fields had been harvested within the previous 3 to 5 months. In all, 8 fields were surveyed in 1997 and 16 in 1998. Most fields surveyed in 1997 had a high incidence of ALB in the previous carrot crop, but most fields surveyed in 1998 had little or no ALB in the previous carrot crop. Volunteer carrot plants and miscellaneous weeds within and adjacent to surveyed fields were examined for lesions similar to those induced by $A$. dauci. Leaves with symptoms potentially caused by $A$. dauci were collected from 5 to 10 volunteer carrot plants in each field surveyed. Several sections (approximately $5 \mathrm{~mm}^{2}$ ) were taken from suspect lesions on each sampled leaf and surface disinfested in $10 \%$ household bleach (The Clorox Co., Oakland, CA) for 10 to $30 \mathrm{~s}$. Sections were placed in petri dishes containing acidified ( $1.25 \mathrm{ml}$ of $25 \%$ lactic acid/liter of agar) potato dextrose agar (PDA; Difco Laboratories, Detroit) and incubated under Coolwhite fluorescent lights (F20T12/CW; Osram Sylvania, Danvers, MA) for 5 to 7 days at $22^{\circ} \mathrm{C}$ with a 12 -h light period each day. Similar-sized leaf sections that had not been surface disinfested were placed in humidity chambers (15-by-100-mm petri dishes each containing two filter paper discs moistened with $2 \mathrm{ml}$ of sterile water) and incubated under fluorescent lights for 3 days at $22^{\circ} \mathrm{C}$ as described above. After incubation, the leaves were examined for the presence of $A$. dauci conidia.

One typical isolate of $A$. dauci from each field was subcultured on PDA and tested for pathogenicity using a carrot seedling assay. Carrot seedlings (cv. Caropak) were sown in 10 -cm-diameter pots containing a general potting soil mix and watered as needed. Three weeks after emergence, the seedlings (three- to fourleaf stage) were thinned to five plants per pot. Cultures of each suspect $A$. dauci isolate were initiated from single spores and grown on V8 agar plates for 14 days under Cool-white fluorescent lights at $22^{\circ} \mathrm{C}$ (12-h day length). Conidia were collected by flooding each dish with $10 \mathrm{ml}$ of sterile water and dislodging conidia with a glass rod. Conidial suspensions were filtered through two layers of sterile cheesecloth to remove hyphal fragments and diluted with sterile water to $10^{3}$ conidia $/ \mathrm{ml}$. Seedlings were sprayed with conidial suspensions until run-off. A plastic bag was placed over each pot and secured at the base of the pot with a rubber band. The bags were removed after 2 days and the pots placed in a greenhouse mist chamber (misting interval of $5 \mathrm{~s}$ every $3 \mathrm{~h}$ ). The plants were examined for symptoms of ALB after 14 days. Leaves with symptoms were collected, surface disinfected, and plated onto acidified PDA (APDA) to recover A. dauci and verify Koch's postulates.
Five weed species exhibiting ALB-like symptoms were collected from the fields sampled for volunteer carrot plants in 1997 and seven weed species were collected in 1998. Four or five samples of each species were collected each year. Leaves were assayed for the presence of A. dauci as described for volunteer carrot plants.

Recovery of $\boldsymbol{A}$. dauci from carrot crop residue in California. Carrot crop residue was collected in late winter and early spring (February and March) from the same fallow fields surveyed for volunteer carrot plants and weed hosts in 1997 and 1998. Samples were collected within each field from five 4.3-by-4.3-m plots spaced approximately $65 \mathrm{~m}$ apart. Within each plot, 5 to $15 \mathrm{~g}$ of dry carrot crop residue (whole leaves, leaflets, and petioles) was collected from the soil surface at three randomly selected locations ( 30 by $30 \mathrm{~cm}$ ) and composited. Approximately $100 \mathrm{~g}$ of soil also was collected at the same locations from 10- and 20-cm depths and composited for each depth. Crop residue and soil samples were placed in paper bags and air-dried in the laboratory for approximately 5 to 7 days. After drying, the soil samples were sieved through a US \#20 standard testing sieve and the crop residue was recovered. All surface and buried residue was placed on moistened filter paper in petri dishes (approximately 20 pieces of residue per dish, 5 to 15 dishes per sample) and sealed with parafilm. Dishes were incubated under fluorescent lights for 3 days at $22^{\circ} \mathrm{C}$ (12-h day length) and examined microscopically for the presence of $A$. dauci conidia growing from the surface of the residue. When $A$. dauci was observed, two isolates were randomly selected from each field and pathogenicity tests were performed as described above.

Survival of $A$. dauci associated with carrot leaf tissue in California fields. These studies were conducted in one fallow field and one irrigated field where a crop other than carrot was being grown. The soil in each field was a sandy loam type. A. dauci-infested carrot leaves were produced in a greenhouse mist chamber from carrot plants grown in 10-cm-diameter pots. Carrot leaves were inoculated after 8 weeks of growth with a conidial suspensions of $A$. dauci produced on V8 agar plates as described above. Two weeks after inoculation, leaves with symptoms of ALB on more than $50 \%$ of the leaf surface were collected and air-dried in paper bags at ambient laboratory conditions. Dried leaf tissue ( $2 \mathrm{~g})$ was placed in a square envelope $(10$ by $10 \mathrm{~cm})$ made from fiberglass window-screen material, and the envelope was closed by stapling.

Within each field, five sites ( 30 by 30 $\mathrm{cm}$ ) were selected approximately 20 to 50 $\mathrm{m}$ apart. At each site, four envelopes were placed on the soil surface and four were buried $10 \mathrm{~cm}$ deep. For both fallow and irrigated sites, envelope placement was conducted in June. Following envelope placement, each site was covered with a piece of $0.5-\mathrm{cm}-\mathrm{mesh}$ screen to prevent envelope movement and disturbance by surface-foraging animals. One surface and one buried envelope were recovered from each site 1, 3, 7, and 12 months after placement. Leaf tissue recovered from each envelope was placed in separate paper bags and air-dried under ambient laboratory conditions for approximately 5 to 7 days. After drying, the leaf tissue was assayed for $A$. dauci as described above. The presence of $A$. dauci conidia was scored using a rating system where $1=$ no conidia observed, $2=$ sparse sporulation $(<10$ conidia per dish), $3=$ moderate sporulation (10 to 50 conidia per dish), and $4=$ abundant sporulation ( $>50$ conidia per dish). Controls consisted of infested leaf tissue in envelopes kept under ambient laboratory conditions and evaluated with field samples at each sampling date. The experiment was carried out in 1997 and in 1998 with different field locations each year. In 1997, the selected irrigated field was in rose production and in 1998, the selected irrigated field was in alfalfa production. A $\chi^{2}$ analysis was used to test the independence of sporulation score and irrigation, and the independence of sporulation score and burial of sample.

Survival of A. dauci associated with carrot leaf tissue under greenhouse conditions. A. dauci-infested carrot leaf tissue was produced in a greenhouse mist chamber as described above. Dried leaf tissue (2 g) was placed in fiberglass window-screen envelopes as described above. Sandy loam soil was collected in Kern County, CA, from a field in which carrot had not been grown for at least 5 years. Six 20-liter plastic pots were filled with the soil and eight envelopes containing infested carrot leaf tissue were placed in each pot; four on the soil surface and four at a depth of 10 $\mathrm{cm}$. For each experiment, three pots were not watered, and three pots were watered weekly. A surface and a buried envelope were recovered from each pot $1,3,7$, and 12 months after placement. The leaf tissue from each envelope was assayed for the presence of $A$. dauci as described above. Control envelopes also were assayed at each sample date. This experiment was conducted in 1998 and 1999. A $\chi^{2}$ analysis was used to test the independence of sporulation score and irrigation, and the independence of sporulation score and burial of sample.

Survival of $A$. dauci associated with carrot leaf tissue in Florida fields. Leaves with symptoms of ALB were collected in 1992 from carrot plants (cv. HiColor 9) severely damaged by ALB. Carrots had been grown in an experimental breeding plot and received no fungicides. The leaves collected were mostly green with minimal yellowing and moderate levels (about $40 \%$ ) of necrotic tissue. Five 
leaflets (average total area, approximately $6 \mathrm{~cm}^{2}$ ) were removed and folded tightly into a piece of fiberglass window-screen material. Each packet was placed into a polypropylene histology embedding capsule with open mesh bottom and lid (2.9 $\mathrm{cm}$ in diameter and $0.6 \mathrm{~cm}$ thick; \#152182-219; Fisher Scientific, Pittsburgh, PA). The remaining capsule volume not occupied by the packet was filled with coarse builders sand. In March 1992, capsules were buried $20 \mathrm{~cm}$ apart and $15 \mathrm{~cm}$ deep in a freshly plowed field (Myakka fine sand, $\mathrm{pH} 6.4,<2 \%$ organic matter) that had never had carrot grown in it. No crops were planted in the plot area, and the plot was periodically treated with a contact herbicide to control weeds. At approximately 2week intervals for 37 weeks after burial, one capsule was retrieved from the plot by a previously-attached wire lead. Contents of the fiberglass packet was divided into three equal portions and four subsamples of each portion were evenly distributed on a petri dish containing a selective agar medium. The selective medium was made from carrot leaf agar (19) supplemented with benomyl at $0.4 \mathrm{mg} / \mathrm{ml}$, metalaxyl at $0.4 \mathrm{mg} / \mathrm{ml}$, and streptomycin sulfate at 0.02 $\mathrm{mg} / \mathrm{ml}$. Dishes were incubated under Coolwhite fluorescent lights (16-h day length) for 7 days at $20^{\circ} \mathrm{C}$, then examined microscopically for growth and sporulation of $A$. dauci. The presence of $A$. dauci conidia was scored using a rating system where $1=$ no conidia observed, $2=$ sparse sporulation, $3=$ moderate sporulation, and $4=$ abundant sporulation on leaf tissue and agar.

Infectivity of $A$. dauci associated with carrot crop residue. A commercial carrot crop growing on organic soil (Terra Ceia Muck, pH 6.4, approximately $80 \%$ organic matter) near Lake Jem, FL, in 1991 was severely damaged by ALB. On 20 February, 2 days after harvest, crop residue was incorporated into the soil. The field was planted with sweet corn 8 days after residue incorporation and was subsurface irrigated. Three weeks after the residue had been incorporated, 10 soil samples (approximately 2 liters each) were collected from the upper $10 \mathrm{~cm}$ of soil at random locations within a sampling area of 1,000 $\mathrm{m}^{2}$. The samples were pooled for a total sample volume of 20 liters. Subsequent soil samples were collected at approximately 2-week intervals for 16 weeks. Each soil sample was passed through a 1$\mathrm{cm}$-mesh screen to remove larger pieces of plant residue and the screened soil was used to fill three plastic trays ( 28 by 53 by $6 \mathrm{~cm}$ ). Five hundred carrot seed (cv. Spar$\tan$ Fancy) were planted at a depth of $1 \mathrm{~cm}$ in each tray. Trays were placed in an environmental room maintained at $20^{\circ} \mathrm{C}$ with Cool-white fluorescent lighting $(150 \mathrm{~mol}$ $\mathrm{sec}^{-1} \mathrm{~m}^{-2}, 16-\mathrm{h}$ day length) and watered as needed. Seedlings were examined every 2 days after emergence for symptoms of infection by $A$. dauci. Seedlings infected by $A$. dauci may develop symptoms similar to those associated with damping-off caused by Pythium spp.; therefore, symptomatic seedlings were removed on each day of observation and incubated at $20^{\circ} \mathrm{C}$ under fluorescent lights for $48 \mathrm{~h}$ on moist filter paper in a petri dish. Infection by $A$. dauci was verified by the presence of $A$. dauci conidia produced on diseased hypocotyls. Each tray of seedlings was observed for at least 4 weeks after planting.

The experiment was repeated in a mineral soil (Myakka fine sand, $\mathrm{pH} 6.5,<2 \%$ organic matter) near Sanford, FL, in 1991. Carrot had been grown in an experimental breeding plot ( 0.3 ha) and received no fungicides. The carrot plants became severely damaged by ALB and were not harvested, so the mature crop was incorporated into the soil on 3 April. Following incorporation of the crop, soil samples were collected from the field every 2 weeks for 26 weeks. Soil samples (each approximately 2 liters in volume) were collected from the upper $10 \mathrm{~cm}$ of soil within each of eight randomly selected sample sites $\left(2 \mathrm{~m}^{2}\right)$ on each sampling date. Unlike the field with the organic soil type, the field with mineral soil remained fallow for the duration of the experiment, but was periodically disced to control weeds. Soil samples were passed through a 1-cm-mesh screen to remove larger pieces of plant residue, and the screened soil was used to fill plastic trays ( 12 by 12 by $6 \mathrm{~cm}$ ). One hundred carrot seed were placed on the soil surface and covered with a $1-\mathrm{cm}$ layer of a peat-vermiculite plant growth medium. After emergence, seedlings were examined every 2 days for symptoms of infection by A. dauci as described above. Infection of seedlings by $A$. dauci was verified as described for the experiment carried out in the organic soil.

Infectivity of $A$. dauci associated with carrot crop residue in flooded soils. To examine the infectivity of $A$. dauci associated with carrot crop residue in flooded soils, organic soil was collected from a celery field near Lake Jem, FL, in 1992. Infected carrot leaf tissue collected from diseased, field-grown carrots was air-dried in the laboratory, finely chopped, and mixed thoroughly with the organic field soil that had been screened as described above. The leaf tissue to soil ratio was 1:38 (vol/vol). Fifty plastic pots each were filled with $110 \mathrm{~cm}^{3}$ of this mixture and placed in a greenhouse. Half of the pots were placed in plastic tubs to which tap water was added until pots were covered with $10 \mathrm{~cm}$ of water. The water level was maintained by adding additional water periodically.

Table 1. Recovery of Alternaria dauci from volunteer carrots and carrot crop residue collected from fallow carrot fields in Kern County, CA, during the spring of 1997 and 1998

\begin{tabular}{|c|c|c|c|c|}
\hline \multirow[b]{2}{*}{ Year, field } & \multirow[b]{2}{*}{ Volunteer ${ }^{\mathbf{b}}$} & \multicolumn{3}{|c|}{ Residue (positive samples/total samples) ${ }^{\mathbf{a}}$} \\
\hline & & Surface & $10 \mathrm{~cm}$ & $20 \mathrm{~cm}$ \\
\hline \multicolumn{5}{|l|}{1997} \\
\hline A1 & + & $5 / 5$ & $5 / 5$ & $1 / 5$ \\
\hline A2 & + & $5 / 5$ & $5 / 5$ & $2 / 5$ \\
\hline K1 & + & ns & $\mathrm{ns}$ & ns \\
\hline K2 & + & ns & $\mathrm{ns}$ & ns \\
\hline S1 & + & $0 / 5$ & $3 / 5$ & $2 / 5$ \\
\hline $\mathrm{S} 2$ & ns & ns & $5 / 5$ & $4 / 5$ \\
\hline SF1 & ns & ns & $2 / 5$ & $1 / 5$ \\
\hline SF2 & + & $5 / 5$ & $5 / 5$ & $5 / 5$ \\
\hline SF3 & + & ns & ns & ns \\
\hline \multicolumn{5}{|l|}{1998} \\
\hline A3 & + & $5 / 5$ & $2 / 5$ & $4 / 5$ \\
\hline A4 & + & $5 / 5$ & $2 / 5$ & $4 / 5$ \\
\hline A5 & + & ns & ns & ns \\
\hline A6 & - & ns & ns & ns \\
\hline $\mathrm{C} 1$ & + & ns & $\mathrm{ns}$ & ns \\
\hline $\mathrm{C} 2$ & - & $0 / 5$ & $3 / 5$ & $5 / 5$ \\
\hline $\mathrm{C} 3$ & + & ns & $\mathrm{ns}$ & ns \\
\hline M1 & + & $2 / 5$ & $4 / 5$ & $5 / 5$ \\
\hline M2 & + & ns & ns & ns \\
\hline M3 & - & $2 / 5$ & $0 / 5$ & $0 / 5$ \\
\hline M4 & + & ns & ns & ns \\
\hline M5 & + & ns & $\mathrm{ns}$ & ns \\
\hline $\mathrm{O} 1$ & + & ns & ns & ns \\
\hline S3 & + & $5 / 5$ & $3 / 5$ & $5 / 5$ \\
\hline S4 & + & ns & ns & ns \\
\hline SF4 & + & $5 / 5$ & $5 / 5$ & $5 / 5$ \\
\hline
\end{tabular}

a Samples of carrot crop residue were collected within each field from five plots (4.3 by $4.3 \mathrm{~m})$ spaced approximately $65 \mathrm{~m}$ apart. Within each plot, residue was collected at three separate locations from the soil surface and composited. Soil was also collected from 10- and 20-cm depths at the same locations and composited by depth. A positive sample indicates the presence of $A$. dauci sporulation induced in the laboratory on samples of residue collected within a field; ns indicates no samples were taken.

${ }^{\mathrm{b}}$ Values of + and - indicate the presence and absence, respectively, of A. dauci sporulation induced in the laboratory on samples of volunteer carrots collected within a field. 
The other pots remained on a greenhouse bench with no additional water added. At 7-day intervals for 42 days, four pots were randomly selected from the flooded and nonflooded group of pots and 50 carrot seed (cv. Spartan Fancy) were placed on the soil surface in each pot and covered with a 1- cm layer of vermiculite. Seeded pots were maintained in the same greenhouse and watered as needed. After emergence, carrot seedlings were examined daily for 21 days for symptoms of damping-off caused by $A$. dauci. Infection of seedlings by $A$. dauci was verified using the methods described above.

\section{RESULTS}

Occurrence of $A$. dauci on volunteer carrot plants and weeds in California. $A$. dauci was recovered from lesions on volunteer carrot plants in all fields sampled in 1997 and from 13 of 16 fields sampled in 1998 (Table 1). The pathogen was recovered from approximately $65 \%$ of all lesions sampled in both years (data not presented). Twenty isolates of $A$. dauci recovered from these volunteer carrot plants were tested for pathogenicity on carrot seedlings. All were pathogenic, thereby verifying the identity of the pathogen. In addition, $A$. radicina, causal agent of carrot black rot, was recovered from leaf lesions on volunteer carrot plants from two fields sampled in 1998 (fields A5 and O1).

Weed species collected from fallow fields in 1997 included milk thistle (Silybum marianum), common fiddleneck (Amsinckia intermedia), cheeseweed (Malva parviflora), London rocket (Sisymbrium irio), and California slender nettle (Urtica dioica). Weed species sampled from fallow fields in 1998 included milk thistle, common fiddleneck, cheeseweed, annual sowthistle (Sonchus oleraceus), common knotweed (Polygonum aviculare), black nightshade (Solanum nigrum), and common sunflower (Helianthus annuus). Alternaria dauci was not recovered from foliar lesions on any of the weed species sampled in either year.

Recovery of $\boldsymbol{A}$. dauci from carrot crop residue in California. $A$. dauci was recovered from crop residue in all fields sampled in 1997 and 1998 (Table 1). The fungus was recovered from $69 \%$ of all samples of residue (surface, $10-\mathrm{cm}$, and $20-\mathrm{cm}$ depths) in 1997 and from 68\% of all samples of residue in 1998. In 1997, the fungus was
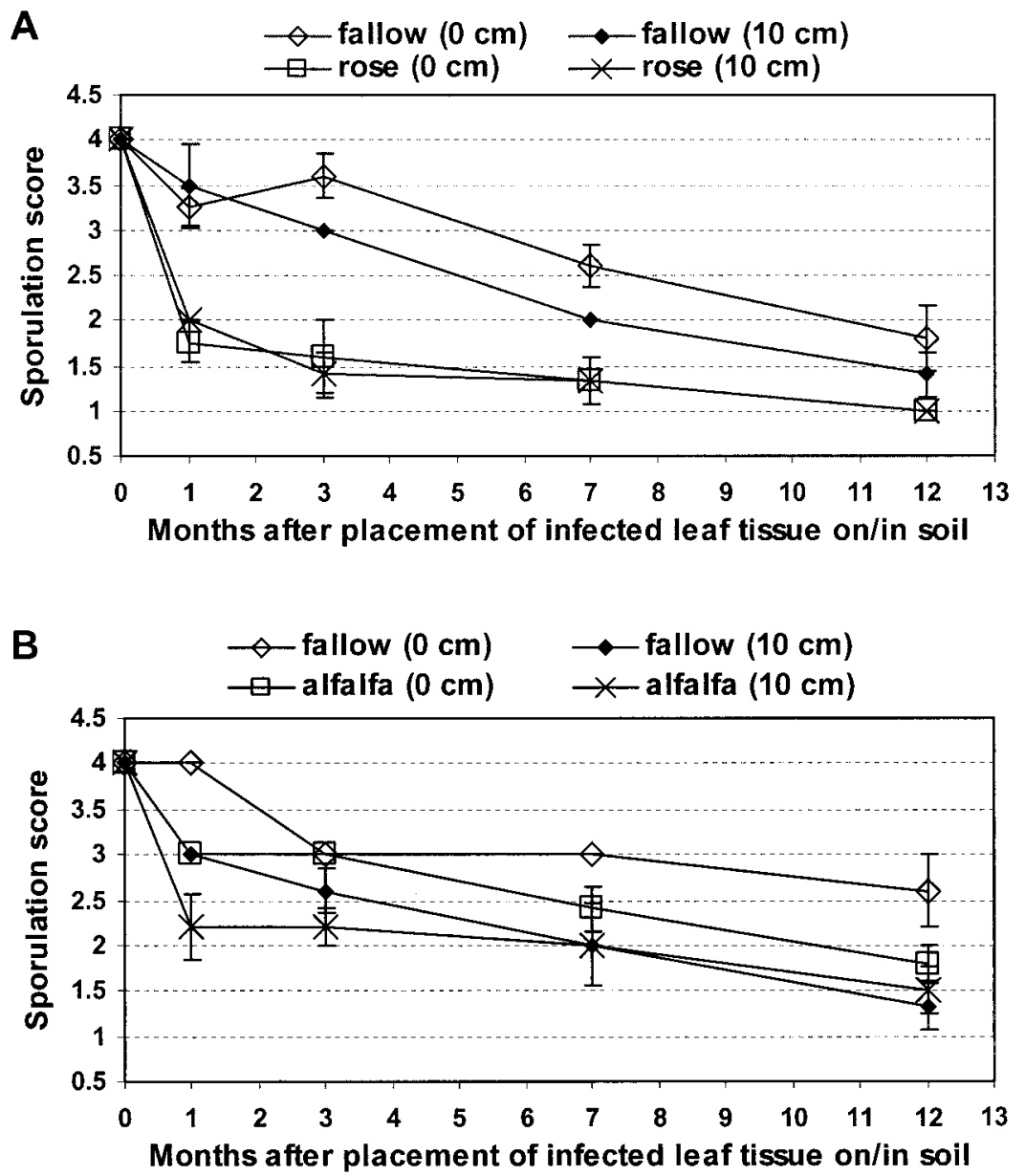

Fig. 1. Sporulation of Alternaria dauci on carrot leaf tissue placed on or in a sandy loam soil and recovered after 1, 3, 7, and 12 months in California in A, 1997 and B, 1998. Sporulation of A. dauci on recovered tissue was scored based on a rating system where $1=$ no conidia observed, $2=$ sparse sporulation, $3=$ moderate sporulation, and $4=$ abundant sporulation. recovered from $75 \%$ of all samples collected at the soil surface, from $83 \%$ of samples collected from the $10-\mathrm{cm}$ depth, and from $50 \%$ of all samples collected from the 20-cm depth. In 1998, the fungus was recovered from $69 \%$ of all samples collected at the soil surface, from $54 \%$ of all samples collected from the $10-\mathrm{cm}$ depth, and from $80 \%$ of all samples collected from the 20-cm depth. Carrot pathogenicity tests conducted in the greenhouse with selected potential $A$. dauci isolates ( $n$ $=26$ ) were all positive.

Survival of $A$. dauci associated with carrot leaf tissue in California fields. Sporulation of A. dauci was abundant (sporulation rating of 4) on infested carrot leaf tissue after 1,3 , and 7 months of storage in paper bags under ambient laboratory conditions, and moderate to abundant (sporulation rating of 3 to 4 , respectively) on tissue stored for 12 months (data not shown). In fallow fields (i.e., fields not planted to a rotational crop and receiving no supplemental water), A. dauci survived for up to 12 months in association with residue placed on the soil surface or buried (Fig. 1). However, at 7 months after placement of leaf tissue in these fields, sporulation was sparse to moderate on most samples placed at the soil surface and sparse on all buried samples. At 12 months after placement of leaf tissue, sporulation was sparse to moderate on most samples placed at the soil surface and sparse on most buried samples. Sporulation was not detected on $20 \%$ of surface samples and $40 \%$ of buried samples after 12 months in the field. After 7 to 12 months in the field, most leaf tissue (on the surface and buried) had decomposed and the tissue remaining for A. dauci recovery consisted primarily of petiole tissue.

A. dauci survived on carrot leaf tissue for up to 12 months in an irrigated alfalfa crop but only 7 months in an irrigated rose field (Fig. 1). Sporulation was sparse to moderate on leaf tissue recovered after 1 , 3 , and 7 months in the alfalfa field (Fig. 1A). After 12 months, sporulation of $A$. dauci was sparse and was only detected on $80 \%$ of samples recovered from the alfalfa field. In the rose field, sporulation of $A$. dauci was sparse on all samples recovered after only 1 month in the field. After 3 months, sporulation was only detected on $40 \%$ of the samples recovered from the rose field, and sporulation was only detected on $20 \%$ of the samples recovered from this field after 7 months. Soil moisture was consistently observed to be higher in the rose field at times of envelope retrieval compared with the alfalfa field, and envelopes placed on the soil surface in the rose field were usually heavily colonized by algae. As in the fallow fields, most leaf tissue (surface and buried) decomposed within 7 months, and primarily petiole tissue remained for isolation of $A$. dauci.

A $\chi^{2}$ analysis revealed that the sporulation score for infested carrot tissue recov- 
ered from fields was not independent of soil moisture (fallow or irrigated soil) in both 1997 and 1998 experiments, and was not independent of the location of placement of the leaf tissue (soil surface or buried) in the 1998 experiment (Table 2). However, the sporulation score for infested carrot tissue recovered from fields was independent of location of placement of the tissue (soil surface or buried) in the 1997 experiment (Table 2). Separate $\chi^{2}$ analyses for each field in the 1997 experiment revealed that the sporulation score was independent of location of placement of the tissue in both fields $\left(\chi^{2}\right.$ values of $3.200[P=0.362]$ and $1.295[P$ $=0.523]$ for the fallow field and the rose field, respectively).

Survival of $A$. dauci associated with carrot leaf tissue under greenhouse conditions. Sporulation of A. dauci was abundant (sporulation rating of 4 ) on infested carrot leaf tissue after 1, 3, and 7 months of storage in paper bags under ambient laboratory conditions, and moderate to abundant (sporulation rating of 3 to 4 , respectively) on tissue stored for 12 months (data not shown). In greenhouse experiments, A. dauci survived up to 12 months in association with leaf tissue placed on the soil surface or buried in soil within pots that did not receive water (Fig. 2). Sporulation on this tissue was generally moderate to abundant in 1998 and moderate in 1999 (Fig. 2). Under these conditions, leaf tissue placed on the soil surface or buried remained more or less intact after 12 months. In contrast, sporulation of $A$. dauci was considerably reduced in pots watered weekly, particularly in 1999, when sporulation was not detected on many samples after only 1 month of burial (Fig.
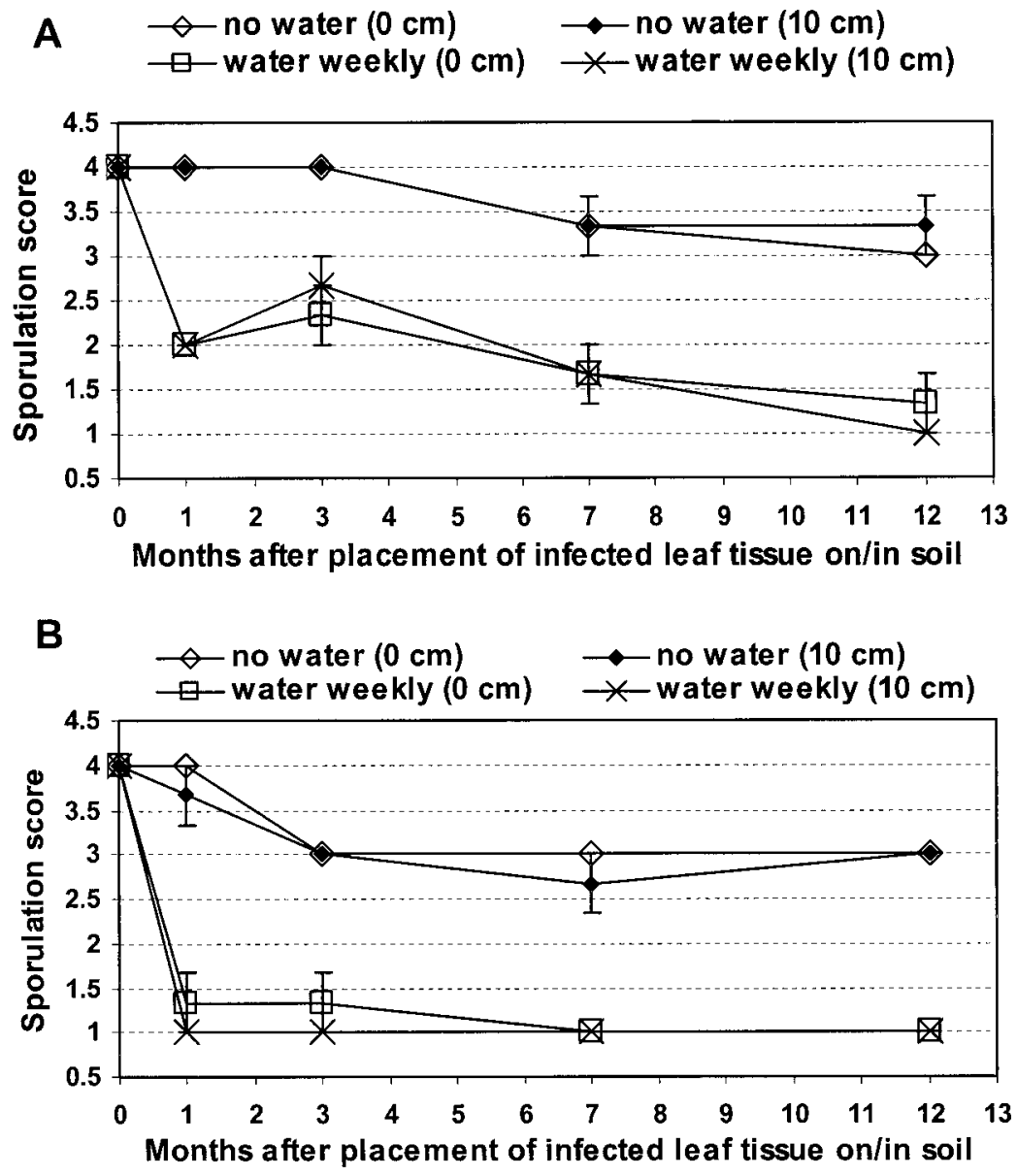

Fig. 2. Sporulation of Alternaria dauci on carrot leaf tissue placed on or in a sandy loam soil and recovered after 1, 3, 7, and 12 months in a greenhouse in $\mathbf{A}, 1998$ and $\mathbf{B}, 1999$. Sporulation of $A$. dauci on recovered tissue was scored based on a rating system where $1=$ no conidia observed, $2=$ sparse sporulation, $3=$ moderate sporulation, and $4=$ abundant sporulation.

Table 2. Independence of the sporulation of Alternaria dauci on carrot leaf tissue tested by $\chi^{2}$ analysis against the variables of applications of water to the soil and location of leaf tissue in the soil in field and greenhouse experiments in California in 1997 to 1999

\begin{tabular}{|c|c|c|c|c|c|c|c|}
\hline \multirow[b]{2}{*}{ Year, site } & \multirow[b]{2}{*}{ Variable $^{b}$} & \multicolumn{4}{|c|}{ Sporulation score ${ }^{\mathrm{a}}$} & \multirow[b]{2}{*}{$\chi^{2}$} & \multirow[b]{2}{*}{$P$} \\
\hline & & 1 & 2 & 3 & 4 & & \\
\hline \multicolumn{8}{|l|}{1997} \\
\hline \multirow[t]{2}{*}{ Field } & Fallow & 5 & 12 & 14 & 7 & $\ldots$ & $\ldots$ \\
\hline & Irrigated & 13 & 12 & 1 & 0 & 20.807 & $<0.001$ \\
\hline \multirow{2}{*}{ Field } & Surface & 9 & 9 & 10 & 4 & $\ldots$ & $\ldots$ \\
\hline & Buried & 9 & 15 & 5 & 3 & 3.310 & $=0.346$ \\
\hline \multicolumn{8}{|l|}{1998} \\
\hline \multirow[t]{2}{*}{ Field } & Fallow & 2 & 8 & 19 & 6 & $\ldots$ & $\ldots$ \\
\hline & Irrigated & 4 & 16 & 17 & 0 & 9.396 & $=0.025$ \\
\hline \multirow{2}{*}{ Field } & Surface & 1 & 10 & 23 & 6 & $\ldots$ & $\ldots$ \\
\hline & Buried & 6 & 14 & 12 & 0 & 12.966 & $=0.005$ \\
\hline \multirow[t]{2}{*}{ Greenhouse } & Dry & 0 & 0 & 9 & 15 & $\ldots$ & $\ldots$ \\
\hline & Wet & 7 & 14 & 3 & 0 & 39.000 & $<0.001$ \\
\hline \multirow[t]{2}{*}{ Greenhouse } & Surface & 3 & 8 & 6 & 7 & $\ldots$ & $\ldots$ \\
\hline & Buried & 4 & 6 & 6 & 8 & 0.495 & $=0.920$ \\
\hline \multicolumn{8}{|l|}{1999} \\
\hline \multirow[t]{2}{*}{ Greenhouse } & Dry & 0 & 1 & 18 & 5 & $\ldots$ & $\ldots$ \\
\hline & Wet & 22 & 2 & 0 & 0 & 45.000 & $<0.001$ \\
\hline \multirow[t]{2}{*}{ Greenhouse } & Surface & 10 & 2 & 9 & 3 & $\ldots$ & $\ldots$ \\
\hline & Buried & 12 & 1 & 9 & 2 & 0.715 & $=0.870$ \\
\hline
\end{tabular}

${ }^{a}$ Variables include application of water (fallow or irrigated in field experiments, dry or watered weekly in greenhouse experiments) and location of carrot leaf tissue (placed at the soil surface or buried $10 \mathrm{~cm}$ deep).

${ }^{\mathrm{b}}$ Sporulation of $A$. dauci on carrot leaf tissue recovered from soil was scored based on a rating system where $1=$ no conidia observed, $2=$ sparse sporulation, 3 = moderate sporulation, and $4=$ abundant sporulation. Values represent the total number of tissue samples recovered 1, 3, 7, and 12 months after placement on or in soil that were scored at the corresponding sporulation level. 
2). As in the field studies, most leaf tissue placed in watered pots had decomposed after 7 months and primarily petiole tissue remained for examination. Similar results were obtained for tissue recovered from unwatered pots in 1998 and 1999, whereas sporulation on tissue recovered from watered pots was greatly reduced in 1999 compared to 1998 (Fig. 2).
A $\chi^{2}$ analysis revealed that the sporulation score of infested carrot tissue recovered from pots was not independent of soil moisture (watered or nonwatered soil), but was independent of location of placement of the tissue (soil surface or buried) in both the 1998 and 1999 experiments (Table 2).

Survival of $A$. dauci associated with carrot leaf tissue in Florida fields. $A$.

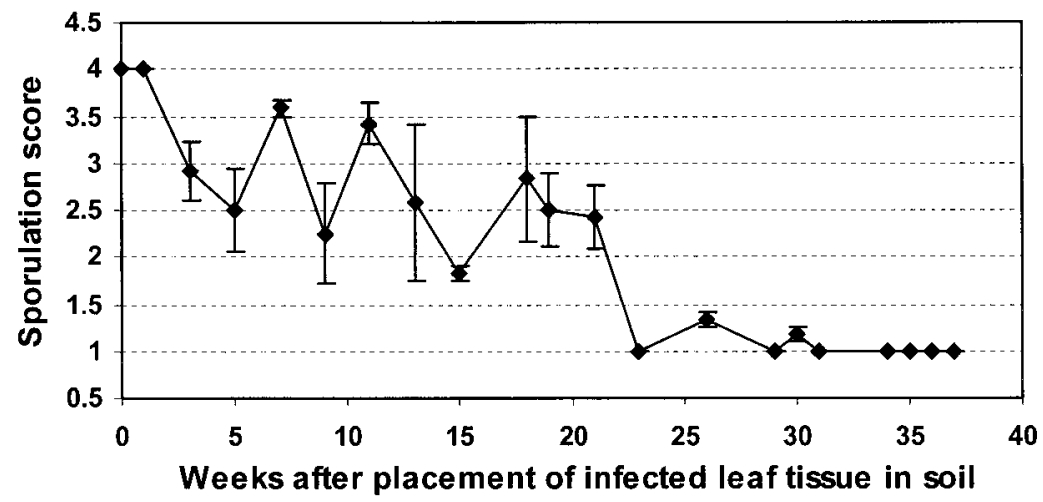

Fig. 3. Sporulation of Alternaria dauci on carrot leaf tissue buried in a mineral soil and recovered at 2-week intervals for 37 weeks in Florida in 1992. The sporulation of A. dauci on recovered tissue was scored based on a rating system where $1=$ no conidia observed, $2=$ sparse sporulation, $3=$ moderate sporulation, and $4=$ abundant sporulation.

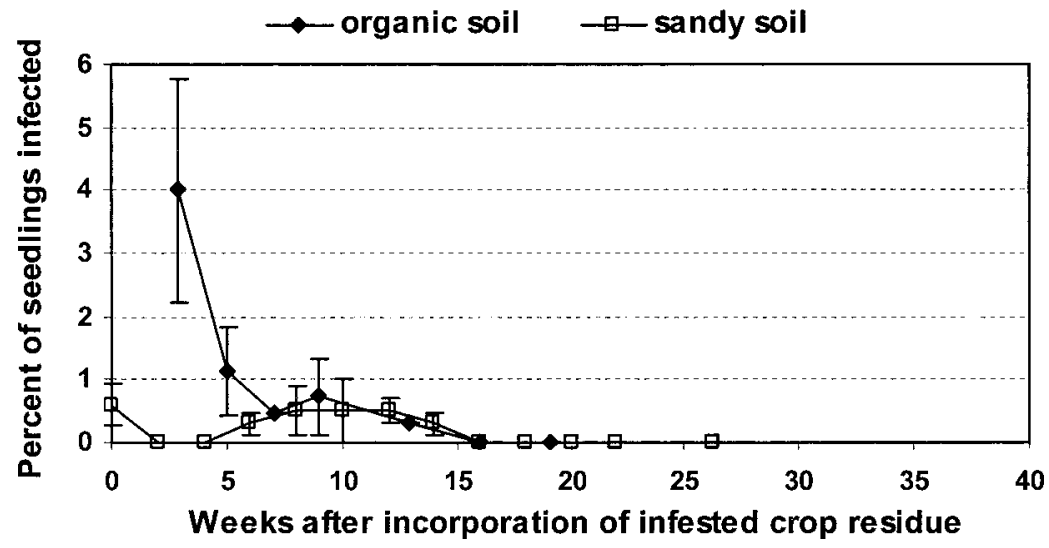

Fig. 4. Percentage of Alternaria dauci-infected carrot seedlings grown in samples of field soil collected at 2-week intervals for 26 weeks following the incorporation of infested carrot crop residue into an organic soil (Histosol) and a mineral soil (fine sand) in Florida in 1991.

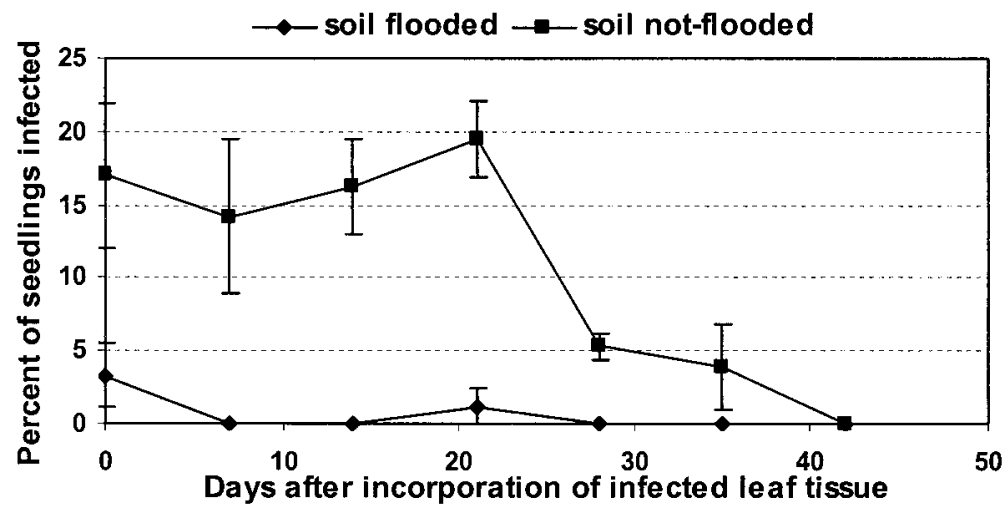

Fig. 5. Percentage of Alternaria dauci-infected carrot seedlings grown in flooded or nonflooded soil samples seeded at 1 -week intervals for 42 days following the incorporation of infected carrot leaf tissue into a mineral soil in Florida in 1992.

dauci was identified on leaf tissue recovered for up to 30 weeks after burial in sandy soil in Florida (Fig. 3). Initially, sporulation was abundant on all leaf tissue recovered, but was greatly reduced after 21 weeks (Fig. 3). For 8 weeks after burial, leaf tissue remained intact, but by 10 weeks the samples recovered consisted of a black, amorphous mass. By 16 weeks, the leaf tissue consisted of a dark residue that remained interspersed within the sand. Nevertheless, $A$. dauci was recovered from the decomposed leaf samples. A. dauci was not identified on leaf tissue recovered after 31 weeks of burial.

Infectivity of $A$. dauci associated with carrot crop residue. Carrot seedlings were infected by $A$. dauci in the organic soil samples collected for up to 13 weeks after infested carrot crop residue was incorporated in this soil (Fig. 4). Carrot crop residue, including pieces of storage roots, could no longer be identified in the samples by 5 to 6 weeks after incorporation. The average percentage of seedlings infected by $A$. dauci declined from a maximum of $4.0 \%$ (at 3 weeks) to $0.3 \%$ (by 13 weeks).

Fewer seedlings were infected by $A$. dauci in the mineral soil and, on some sampling dates, no infected seedlings were detected (Fig. 4). Carrot seedlings were infected by $A$. dauci in soil samples collected up to 14 weeks after incorporation of the infected carrot crop residue, but none were infected in soil samples collected after 16 weeks. Fewer seedlings were infected in mineral soil samples compared with organic soil samples at all sampling intervals.

Infectivity of $A$. dauci associated with carrot crop residue in flooded soils. No seedlings were infected with $A$. dauci in soil kept in pots flooded for 7 to 14 days (Fig. 5). However, a low percentage of seedlings were infected in soil kept in pots flooded for 21 days (Fig 5). No seedlings were infected in soil kept in pots flooded for more than 28 days. A relatively high percentage of seedlings was infected in soil kept in nonflooded pots and seeded 21 days after incorporation of infected leaf tissue. No seedlings were infected in soil kept in nonflooded pots and seeded 42 days after incorporation of infected leaf tissue.

\section{DISCUSSION}

This work investigates the survival and persistence of $A$. dauci on volunteer carrot plants and crop residue in California and Florida, and addresses modes of long-term survival of $A$. dauci in established carrot production areas. The results of this study document the common occurrence of ALB on volunteer carrot plants in fallow fields, illustrating how $A$. dauci can over-season in the absence of carrot crops. Survival on volunteer host plants is not unique to $A$. dauci, because $A$. solani, causal agent of early blight of tomato, can over-season on 
volunteer tomato plants as well (3). A. dauci may have survived in fallow fields in association with the crowns of carrot plants or carrot pieces that developed into volunteers. In a similar manner, A. dauci can survive in association with steckling carrots stored at $4^{\circ} \mathrm{C}$ for 4 months (unpublished data). Alternatively, inoculum for ALB on volunteer carrot plants may have originated from infested foliar residue that remained in the field after harvest. In the fields sampled in this study, foliar residue was visible on the soil surface 3 to 5 months after harvest and in close proximity to volunteer carrot plants. Results showed that this residue supported the sporulation of $A$. dauci, and recovered isolates proved to be pathogenic. Although the carrot residue remaining in the field would degrade continually and diminish as a source of ALB inoculum, populations of $A$. dauci established on volunteer carrot plants would continue to develop and provide an increasing amount of ALB inoculum. Thus, the presence of both infested residue and infected volunteer carrot plants ensures the survival of $A$. dauci between consecutive periods of carrot production and the development of ALB on subsequent carrot crops even in the absence of seedborne inoculum. In addition, the failure to recover $A$. dauci from weeds commonly found in the vicinity of carrot fields damaged by ALB further highlights the prominent role of infested carrot crop residue and infected volunteers in the recurrence of ALB.

Results of this study demonstrate that the duration of survival of $A$. dauci in association with carrot crop residue is strongly influenced by soil moisture. Infested leaf tissue placed in fallow fields in Kern County, CA supported the survival of $A$. dauci for up to 1 year. Average annual rainfall in Kern County is approximately $13 \mathrm{~cm}$; therefore, crop residue in fallow fields would remain dry for much of the year. Different results were obtained with infested leaf tissue placed in irrigated fields where sporulation of $A$. dauci on tissue samples was sparse after 12 months in an alfalfa field and not detected after 12 months in a rose field. The difference in survival of $A$. dauci between the alfalfa and rose crops may be due to the different irrigation practices used in the two fields; the rose crop was irrigated at least once per week, whereas the alfalfa crop was irrigated approximately every 2 weeks. A decreasing amount of sporulation of $A$. dauci was recorded on recovered leaf tissue from the fallow, alfalfa, and rose fields, respectively, which may be negatively correlated with the levels of soil moisture in these fields. These findings are consistent with studies on A. macrospora, which revealed that survival of the pathogen in cotton crop residue decreased with increasing soil moisture (9).

Results of the greenhouse study supported the hypothesis that survival of $A$. dauci in carrot crop residue is negatively correlated with soil moisture. A. dauci was recovered readily from infested leaf tissue kept in, or on, dry soil up to 1 year. In contrast, when the soil was irrigated weekly, sporulation of $A$. dauci was not detected on most samples of leaf tissue collected after 7 months in 1997, and after only 1 month in 1998. The variation in results between the years may be due to differences in the degree of infestation of the leaf tissue used in each year. This difference was not observed on leaf tissue stored in or on soil kept dry.

The amount of sporulation of $A$. dauci on leaf tissue was not independent of the amount of water in the soil both for the field and the greenhouse studies in both years, which further supports the negative relationship between increasing soil moisture and survival of $A$. dauci on infested carrot crop residue. In addition, sporulation of $A$. dauci on leaf tissue was not independent of the placement of tissue on the soil surface or buried in the 1998 field studies, illustrating the beneficial effect of crop residue burial in reducing the capacity of infested residue to support $A$. dauci survival in some situations. However, the amount of sporulation of $A$. dauci was independent of tissue placement on the soil surface or buried in the 1997 field studies, particularly in the rose field. Furthermore, the amount of sporulation of $A$. dauci clearly was independent of tissue placement in greenhouse studies, as revealed by the very low $\chi^{2}$ values obtained from analysis of each year's data. This result probably was associated with the very different environmental conditions in the greenhouse versus field studies. In the fallow fields, periodic rainfall wet both surface and buried tissue. Subsequent drying of this tissue would be faster for surface tissue and slower for buried tissue, resulting in differences in duration of wetness of leaf tissue. Similar differences in the rate of drying of surface and buried tissue probably occurred in the irrigated fields, although less so in the rose field due to higher irrigation frequency. In contrast, both surface-placed and buried leaf tissue in the dry soil treatments remained dry for the duration of the experiments under the controlled conditions of the greenhouse, resulting in little difference in pathogen survival on surface-placed versus buried tissue. The results are consistent with those from studies on A. macrospora survival in cotton crop residue, in which no difference in pathogen survival on surface versus buried residue was observed under dry conditions (9). Similarly, under greenhouse conditions, leaf tissue placed on the surface of soil that was watered weekly probably remained wet longer than tissue placed on the soil surface in field experiments. These results suggest that the beneficial effect of burying crop residue (i.e., accelerating decomposition of the residue and, there- fore, reducing $A$. dauci sporulation) may be less effective in areas of carrot production where buried residue remains dry (e.g., in desert climates) or in areas where residue on the soil surface remains wet for extended periods (e.g., in some tropical climates).

Results of the experiments on sporulation of $A$. dauci on carrot leaf tissue buried in soil in Florida complimented the results of the experiments in California. In Florida, leaf tissue decayed quickly in the moist (average annual rainfall, $175 \mathrm{~cm}$ ) and relatively warm climate. Buried tissue supported moderate to abundant sporulation of $A$. dauci for up to 5 months, but sporulation rapidly decreased with time and was not observed 8 months after burial. These results further support the hypothesis that increased soil moisture reduces survival and sporulation capacity of A. dauci on infested carrot leaf tissue.

Infectivity studies confirmed that $A$. dauci propagules from field-borne carrot crop residue could infect carrot seedlings and result in the development of ALB. Results of the studies conducted in Florida demonstrated that $A$. dauci surviving on carrot residue remained infective approximately 3 to 4 months after the carrot crop residue was incorporated into organic soils, which was several weeks after much of the residue appeared to have decomposed. This suggests that $A$. dauci may survive, at least for a short period, in the absence of carrot crop residue, perhaps as conidia as has been suggested for $A$. radicina (7). This study also revealed that $A$. dauci remained infective for 3 to 4 months following crop incorporation into mineral soil. Differences between experiments conducted in organic and mineral soil in the percentage of carrot seedlings infected by A. dauci may not be associated with soil types as much as differences in the degree of infestation of the original carrot tissue (as observed in the greenhouse studies). In general, the infectivity studies supported results of the studies on survival of $A$. dauci in that under higher soil moisture (e.g., in Florida soils), the recovery of $A$. dauci from carrot crop residue in fallow fields was reduced compared with that observed under lower soil moisture (e.g., in California soils).

Infectivity studies conducted in the greenhouse revealed that few seedlings were infected by $A$. dauci under flooded soil conditions. These results suggest that $A$. dauci does not survive in flooded soils for more than a few weeks. Where feasible, flooding of fields following carrot harvest may be an effective method for reducing fieldborne inoculum of ALB. Fallow flooding, once used extensively to control other soilborne pests of carrot in Florida (20), has been curtailed because of concerns regarding water quality. Nonetheless, flooding of fallow fields may be feasible elsewhere.

Results of this study document the survival and infectivity of $A$. dauci in soils 
under two very different environments: in California, where it is generally hot with minimal rainfall; and in Florida, where it is generally warm with abundant rainfall. $A$. dauci survived and persisted in association with volunteer carrot plants and carrot crop residue, which may explain the persistent problem of ALB in areas of carrot production where carrot fields are densely concentrated. This study highlights the importance of agricultural practices such as tillage (e.g., discing or deep plowing) for destroying volunteer carrot plants and insuring burial of carrot crop residue for management of ALB. These practices may be even more important in cooler growing regions where crop residue decomposition may be slower than in warmer regions. In addition, these results illustrate the importance of crop rotation for at least 1 year to prevent survival of inoculum between carrot crops. Where feasible, flooding of fallow fields also may be an effective disease management tool. The overall effectiveness of any of these disease management practices will have limited success if the management strategies are not coordinated and implemented regionally.

\section{ACKNOWLEDGMENTS}

We thank S. Taylor, K. Stone, and M. Mendoza for their assistance in laboratory work and field work in California.

\section{LITERATURE CITED}

1. Bhaskaran, R., and Kandaswamy, T. K. 1977. Epidemiology of the leaf spot disease of sunflower. East Afr. Agric. For. J. 43:5-8.
2. Fancelli, M. I., and Kimati, H. 1991. Occurrence of iprodione resistant strains of Alternaria dauci. Summa. Phytopathol. 17:135146.

3. Jones, J. P. 1991. Early blight. Pages 13-14 in: Compendium of Tomato Diseases. J. B. Jones, J. P. Jones, R. E. Stall, and T. A. Zitter, eds. American Phytopathological Society Press, St. Paul, MN.

4. Langenberg, W. J., Sutton, J. C., and Gillespie, T. J. 1977. Relation of weather variables and periodicities of airborne spores of Alternaria dauci. Phytopathology 67:879-883.

5. Maude, R. B. 1992. Strategies for control of seed-borne Alternaria dauci leaf blight of carrots in priming and process engineering systems. Plant Pathol. 41:204-214.

6. Patterson, C. L. 1991. Importance of chlamydospores as primary inoculum for Alternaria solani, incitant of collar rot and early blight on tomato. Plant Dis. 75:274-278.

7. Pryor, B. M., Davis, R. M., and Gilbertson, R. L. 1998. Detection of Alternaria radicina and its occurrence in California carrot fields. Plant Dis. 82:891-895.

8. Pryor, B. M., and Strandberg, J. O. 2001. Alternaria leaf blight of carrot. In: Compendium of Umbelliferous Crop Diseases. R. M. Davis and R. N. Raid, eds. American Phytopathological Society Press, St. Paul, MN.

9. Rotem, J. 1990. Overwintering of Alternaria macrospora in cotton debris. Phytoparasitica 18:143-152.

10. Rotem, J. 1994. The Genus Alternaria: Biology, Epidemiology, and Pathogenicity. American Phytopathological Society Press, St. Paul, MN.

11. Schwarz, A., and Mittaz, C. 1998. Control of carrot leaf blight (Alternaria dauci). Rev. Suisse Vitic. Arboric. Hortic. 30:287-290.

12. Simon, P. W., and Strandberg, J. O. 1998. Diallel analysis of resistance in carrot to $\mathrm{Al}$ - ternaria dauci. HortScience 123:412-415.

13. Solel, Z., Timmer, L. W., and Kimchi, M 1996. Iprodione resistance of Alternaria alternata pv. citri from Minneola tangelo in Israel and Florida. Plant Dis. 80:291-293.

14. Soteros, J. J. 1979. Detection of Alternaria radicina and $A$. dauci from imported carrot seed in New Zealand. N. Z. J. Agric. Res. 22:185-190.

15. Soteros, J. J. 1979. Pathogenicity and control of Alternaria radicina and A. dauci in carrots. N. Z. J. Agric. Res. 22:191-196.

16. Strandberg, J. O. 1977. Spore production and dispersal of Alternaria dauci. Phytopathology 76:1262-1266

17. Strandberg, J. O. 1983. Infection and colonization of inflorescence and mericarps of carrot by Alternaria dauci. Plant Dis. 67:13511353.

18. Strandberg, J. O. 1984. Efficacy of fungicides against persistence of Alternaria dauci on carrot seed. Plant Dis. 68:39-42.

19. Strandberg, J. O. 1987. Isolation, storage, and inoculum production methods for Alternaria dauci. Phytopathology 77:1008-1012.

20. Strandberg, J. O. 1987. Flooding for disease control. Pages 48-57 in: Agricultural flooding of Organic soils. Bull. 870. G. C. Synder, ed. University of Florida, Agricultural Experiment Station, Gainesville.

21. Strandberg, J. O. 1988. Detection of Alternaria dauci on carrot seed. Plant Dis. 72:531534.

22. Strandberg, J. O., 1992. Alternaria species that attack vegetable crops: Biology and options for disease management. Pages 157-174 in: Alternaria: Biology, Plant Diseases, and Metabolites. Topics in Secondary Metabolism. Vol. 3. J. Chelkowski and A. Visconti, eds. Elsevier, Amsterdam.

23. Teviotdale, B. L., Hall, D. H., and Wright, D. N. 1978. Fungicide control of Alternaria leaf blight of carrot. Calif. Plant Pathol. 41:4-6. 